\title{
Financial implications of a change to LIFO inventory valuation
}

\author{
C. Firer and N. Mowszowski \\ Graduate School of Business Administration, University of the Witwatersrand, Johannesburg
}

A number of South African companies have, in recent years, changed their method of inventory valuation to the last in, first out (LIFO) technique. The implications of such a change go far beyond merely reducing reported earnings and inventory levels. This article examines the effect of LIFO on some key financial variables of companies. It also considers the extent to which listed companies in South Africa have communicated with the market in order to ensure that the perceptions of such in. terested parties as shareholders. lenders and analysts are not distorted by the differing methods of accounting.

S. Afr. J. Bus. Mgmt. 1984, 15: $71-79$

'n Aantal Suid-Afrikaanse maatskappye het in die laaste paar jaar hul metode van inventaris-valuasie na die laaste in, eerste uit (LIEU)-metode verander. Die implikasies van so 'n verandering is veel meer as slegs ' $n$ vermindering in die gerap. porteerde verdienste en inventaris-vlakte. Hierdie artikel bekyk die effek van LIEU op sekere belangrike finansiële maatstawwe van maatskappye. Dit bespreek ook die mate waarin gelyste maatskappye in Suid-Afrika die konsep aan die mark verduidelik het, spesifiek om te verseker dat aandeelhouers, geldskieters en finansièle analitikusse die implikasies verstaan.

S.-Afr. Tydskr. Bedryfsl. 1984, 15: $71-79$

\section{Firer* and N. Mowszowski}

Graduate School of Business Administration, University of the

Witwatersrand, P.O. Box 31170, Braamfontein 2017,

Republic of South Africa.

"To whom correspondence should be addressed

\section{Introduction}

Recently, a significant number of companies have adopted LIFO (last in, first out), as against FIFO (first in, first out), average cost or any other method of valuing their inventories.

A survey by a firm of Chartered Accountants in South Africa (Alex Aiken \& Carter, 1983) disclosed that twenty-six industrial companies whose shares are listed on the Johannesburg Stock Exchange (JSE) changed to LIFO during the year ended June 1983, bringing the total number of industrial company LIFO users on the JSE to ninety-two or $31 \%$ of the listed industrial companies. This compares with $12 \%$ as at June 1981.

Companies which are contemplating adopting LIFO (and indeed, companies who have already done so) are faced with what is commonly referred to as the LIFO dilemma. There are two hypotheses which have been postulated, giving rise to this dilemma. According to Counihan and Watts (1978), these are:

(i) Firstly the stock market could be misled by the reduced [reported] income and fix a [stock] price equal to or lower than the present price. This is the 'functional fixation' hypothesis.

(ii) The second alternative is that the stock market recognizes the increased value of the firm [equivalent to the present value of the cash-flow benefits obtained due to the deferral of tax] and increases the stock price [accordingly]. This is a consequence of the 'efficient markets hypothesis'.

For as long as inflation is prevalent, this dilemma will exist. In inflationary times, one of management's most urgent tasks is to ensure that the firm which it is managing has developed an adequate flow of cash in order that any assets which are consumed (either through the course of being used in the process of production or by being sold to customers as a product per se) can be replaced, thereby securing the survival and potential growth of the firm.

This article examines the effect of LIFO on some key financial variables of companies as well as the extent to which listed companies in South Africa have communicated with the market in order to ensure that the perceptions of interested parties (such as shareholders, creditors, lenders, investors, analysts and competitors, both current and prospective) are not distorted by the differing methods of accounting.

\section{Financial and commercial implications}

The tax and accounting implications of LIFO arise at the end of a company's financial year. However, the firm operates throughout the year. The introduction of LIFO by a firm has 
potential impact on many aspects of its day to day running, stemming either from the requirements of a change to LIFO or from accounting or tax implications. Each firm must assess the effect which each of the factors mentioned below could have on its own operations and then weigh the advantages against the disadvantages before arriving at a decision. The decision is an extremely important one as it cannot later be reversed without the consent of the Commissioner for Inland Revenue (CIR).

Consequently, it is suggested that the decision should be taken by senior management en bloc in order to ensure that every department which is influenced by a switch to LIFO (e.g. accounting, finance, marketing, production, purchasing, warehousing, personnel etc.) is equipped to handle its effects and to contribute towards the optimization of the use of the method.

Managers considering whether to adopt LIFO will be greatly assisted by forecasts of the effects of LIFO on anticipated financial results and cash flows. If the organization has drawn up a long-range plan, the financial plan should be adjusted for the effects of LIFO and evaluated. Alternatively, where LIFO is applied to many categories of inventory subject to different rates of inflation and volume fluctuations, it may be appropriate to undertake a separate exercise to consider the effects of LIFO under alternative conditions. Key factors to be evaluated in these forecasts include:

(i) the effects of the alternative LIFO methods;

(ii) alternative projected future inflation rates;

(iii) fluctuations in inventory volumes;

(iv) the categories of inventory to be valued on LIFO;

(v) the composition of LIFO inventory 'pools';

(vi) sensitivity of LIFO results to changes in sales volumes and prices;

(vii) break-even sales and fixed charge coverage under LIFO.

Sampling techniques may be used to determine the potential effect of LIFO on various inventory categories to provide a guide for future values.

\section{Share price}

Will there be an effect on the share price if a firm switches to LIFO? If the answer is positive, will the results be an increase in share price (due to the enhanced cash flow) or a decrease (due to investors perceiving only the lower reported earnings)?

If share prices were to be adversely affected by a switch to LIFO (i.e. share prices lower than if say FIFO were used) due to the operation of the functional fixation theory, this could lead to an increased cost of capital. Consequently, firms using a discounted cash flow approach to capital budgeting would, because of the use of too high a discount rate, reject projects which they may otherwise have undertaken. Such foregone investment opportunities will certainly not lead to maximization of shareholders' wealth. However, if investors recognized the benefits of a switch to LIFO in terms of increased cash flow, then, ceteris paribus, economically viable projects would be undertaken and there would be no stagnation in growth of the firm or its shareholders.

In attempting to answer questions such as these, the issue of market efficiency must be raised. This has been dealt with at length in numerous articles and books (for example Fama, 1970; Brealey \& Myers, 1981; Gilbertson \& Roux, 1977; Gilbertson \& Vermaak, 1982).

An investigation into stock market behaviour resulting from a firm's switch to LIFO should be examined under the category of the semi-strong form of market efficiency.

According to Knight (1981), two of the implications of the efficient market hypothesis are that:

(i) in an efficient market, share prices adjust quickly and without bias to new information; and

(ii) the information is effectively impounded into share prices.

What is of major concern here is the impact which a change to LIFO will have on share prices, not only at the time of announcement of a change or the change itself, but also on an on-going basis, i.e., is the market functionally fixated (does it believe only the earnings figures it sees?) or is it efficient (does it recognize that accounting techniques, only change figures and not the economic position of a company?)

In a South African study, Knight and Affleck-Graves (1983), concluded that the announcement of a switch to LIFO has a substantial negative impact on share returns which seems to be directly proportional to the extent to which FIFO earnings are reduced by the LIFO adjustment. They also found that the negative impact is impounded into prices sluggishly. They therefore suggested double inefficiency of the JSE. Having studied the effect of switches to LIFO by companies up to November 1980, they also found, however, that the market seems, in the case of the most recent changes, to be impounding the informational content of a switch to LIFO much more rapidly and the negative impact has also been less pronounced. They concluded that the market appears to be learning how to interpret the change to LIFO.

Another major possible consequence of a lower share price is that of the susceptibility to take over. A firm with a share price lower than its 'true' value leaves itself open to being snatched up by a predator who realizes what the 'true' value is. This aspect could, for example, have profound implications for firms where control is not vested in one party.

\section{Earnings, cash flow and assets}

The effect of LIFO is to reduce reported earnings and asset values. Ostensibly cash flow, which is usually defined as net profit after tax plus non-cash items such as depreciation, is also reduced due to the fact that for every $\mathrm{R} 1$ reduction in net profit before tax, there is only a $46,2 \mathrm{c}$ reduction in tax, assuming a tax rate of $46,2 \%$. Therefore, for every $R 1$ reduction in inventory value due to LIFO, there is a reduction in cash flow (as defined above) of 53,8c. However, in this sense, the definition of cash flow can be said to be fallacious i.e., how can cash flow have reduced, yet there is more cash in the bank? For every R1 of LIFO adjustment the true situation is in fact as follows:

$\begin{array}{ll}\text { Nature of effect } & \text { Effect } \\ \text { Cash flow } & \text { Increased by } 46,2 \mathrm{c} \\ \text { Reported net income } & \text { Decreased by } 53,8 \mathrm{c} \\ \text { Shareholders' funds } & \text { Decreased by } 53,8 \mathrm{c} \\ \text { Tax liability } & \begin{array}{l}\text { Decreased by } 46,2 \mathrm{c} \text { (equivalent } \\ \text { to cash in the bank) } \\ \text { Decreased by } 100 \mathrm{c}\end{array} \\ \text { Inventory } & \text { D }\end{array}$

Therefore, while reported earnings, cash flows and asset values are lower, there is no doubt that these figures are of a better quality than under other inventory valuation methods, in that the net effect is that there is more cash in the bank. As is discussed later, this has profound implications on dividend policies, borrowing powers and gearing, and liquidity and 
profitability ratios, i.e. all the indicators which are extracted from the financial statements on a LIFO basis are enhanced when compared to those on a FIFO basis, since there is built in a reserve equivalent to the present value of the interest saving as a consequence of the tax deferred.

It is also important to note that the longer a firm has been using LIFO, the higher the discrepancy between LIFO value of inventory as reflected in its accounts and the current value (assuming that some layers of inventory have been present for many years without being totally eroded). This places LIFO inventory in a similar class to land and buildings with respect to its balance sheet value, both items usually standing in the balance sheet at historical costs. Therefore, unless some information is given in the notes to the accounts as to the current value (ideally replacement value), the entire notion of a balance sheet becomes meaningless.

The concept of cash flow, as referred to in this paper, is thus taken to mean LIFO profit after tax plus the pre-tax LIFO adjustment.

\section{Price reductions}

It can be shown that where prices of a certain item or category of items have fallen rather than risen, the effect would be a lower charge to the income statement in respect of cost of sales under the LIFO method than under any other method. Consequently, reported earnings (both for financial statements and tax) will be increased and a higher tax liability will arise. Any firm which is in an industry where this phenomenon is typical should therefore steer clear of LIFO, at least in respect of those items where prices are constantly falling. Typical examples of such industries are 'high-tech' industries such as computers, video games and digital watches, where current price levels are fractional compared to those of several years ago.

However, if price reductions are temporary, e.g., restricted to one particular year, LIFO should only be switched to in the year following that in which the prices are falling, provided it is anticipated that price levels will start rising once again.

It must be borne in mind that the CIR is not likely to approve a switch away from LIFO if the effect of this will be a reduction of tax payable. Careful pre-planning and postimplementation monitoring is required in order to ensure optimal use of LIFO.

This feature of LIFO can lead to volatility in tax payments and must therefore be regarded as one of the factors increasing the risk of investing in companies in which it is likely to occur.

\section{Inventory management and maintenance of layers}

LIFO postpones reporting inventory profits only with respect to unliquidated inventory balances. If inventory levels are reduced, older costs are matched with current sales prices. During periods of inflation, such older costs will be matched with current sales prices and the inventory profits previously postponed will be recognized. This means that the taxes on inventory profits which were postponed in prior years may be recouped by the government and fall due at one time.

A major factor which affects a LIFO company is therefore that of maintenance of inventory layers. A temporary fall in inventory levels leads to permanent erosion.

Year-end inventory levels may be reduced for a number of reasons, such as strikes, shortages of raw materials, transport delays, unexpected demand, changing fashion, obsolescence, fire or theft, and optimization of inventories for financial reasons. However once a layer has been eroded it cannot be reconstructed. Any future additions to layers will be at current (higher) costs.

It is therefore possible that surplus inventory would be held purely to maintain the layer. It then becomes essential to balance the cost of holding such surplus inventories (perhaps only for a short period, i.e., at least over the financial yearend - they can be liquidated again at the beginning of the new year) against the loss of benefits which will arise if a layer (or part thereof) is eroded. This problem has two main implications:

(i) The initial timing of a change to LIFO should usually coincide with the base inventory being 'normal' and not inflated by recent unusual bulk purchases in excess of normal requirements.

(ii) The pools (in the case of the rand value method) or individual quantities (in the case of the specific goods method) should be closely monitored regularly towards the end of the financial year.

The requirement of maintaining layers in order to perpetuate the LIFO benefit is, in itself, an additional risk inherent in some LIFO companies which should be borne in mind when evaluating the company.

Additional risks are that fire or large-scale thefts will erode a layer just prior to the end of a financial year without sufficient time being available to replenish it before the year-end. In such a case, all the benefit previously arising from a LIFO valuation of such a layer will be lost. All the previously deferred tax will now have to be paid. It may be contended that such as risk (i.e., of unexpectedly having to pay back previously deferred tax) cannot be insured against as no loss will have been incurred, merely the actualization of an existing liability.

Finally, it should be noted that LIFO could still be beneficial in times of reducing inventory levels and should not be spurned merely for the reason that inventory levels are likely to fall. Hoyle (1981) concluded that:

(i) assuming prices do not fall, a company should always benefit financially from adopting LIFO. Even if all the LIFO benefits are later reversed, the company has enjoyed cash benefits from the delayed payment of taxation;

(ii) net LIFO benefits can still occur when normal inventory levels decrease. It depends on whether the LIFO benefits arising on the remaining inventory are greater than the cumulative LIFO benefits on the inventory reduction;

(iii) where inventory levels decrease, then the longer the period that inventories have been held and the higher the inflation rate during that period, the greater will be the LIFO disadvantage;

(iv) a reduction in normal inventory levels may still result in a net LIFO benefit. However, the net LIFO benefit would have been greater if the previous inventory levels had been maintained;

(v) management of year-end inventory levels becomes an increasingly important function in the years subsequent to the introduction of LIFO. Inflation causes increasingly large LIFO benefits to accumulate on inventory levels. The larger the accumulation, the greater will be the loss of cumulative LIFO benefits if inventory levels fall;

(vi) a temporary increase in inventory levels, which is reversed in the subsequent year, does not bring any LIFO benefits in the subsequent year when inventory levels return to normal.

Thus, a decrease in inventory levels can never, in itself, put a company in a more unfavourable tax position than it would have been had it not switched to LIFO. The worst result of 
such a decrease will be a partial or complete reversal of LIFO tax allowances previously claimed. Since these allowances would not have been available to a non-LIFO company in the first place, it is evident that the fear of diminishing inventory levels is misplaced, as, even in extreme circumstances, a oneyear deferral benefit will still occur.

\section{Interim reporting and management accounting}

JSE regulations, provisions of the Companies Act and Generally Accepted Accounting Practice require that interim financial statements be prepared using the same accounting practices utilized in preparing annual financial statements. This becomes difficult when LIFO valuation of inventories has been adopted since the full impact of LIFO is normally not known until the year-end. Therefore, the necessary internal reporting must be developed to measure the inventory volume and price level in order to estimate realistically, the interim inventories on a LIFO basis. In addition, judgement must be applied as to whether decreases in inventory levels represent permanent or temporary liquidations during the year for which replacement reserves should be provided.

A major problem also exists with regard to internal management accounting and control. Terms such as earnings, return on capital, inventory, turnover and gross profit margins must be accurately defined so that the performance of those people responsible for the running of the firm can be evaluated. The definitions must also be clearly communicated to those responsible for setting the firm's operating budgets. A sector of the firm which can also be affected is that group of people, a portion of whose remuneration consists of a share of profits or some other incentive bonus based on performance. Once again, clear definitions must be laid down to avoid later confusion or dissention amongst such employees. Also, cash-flow forecasts derived from LIFO-based management accounts may require adjustment to take into account the replacement value of inventories.

\section{Cost of keeping records}

Keeping inventory records adequate to implement the LIFO method may, in some cases, be extremely costly. These additional records must be audited, which will also add to the cost.

An evaluation of all such costs must be carried out before the switch is made, although it is hardly likely that the total additional costs incurred would deter a company from making the switch as the potential benefits are likely to be substantially greater than the costs. Nevertheless, the company's auditors, data processing manager and procurements manager should be consulted to establish the means by which adequate records are to be kept.

\section{Marketing}

Although it would seem that the concept of matching current costs against current incomes (yielding current net income) could affect the determination of selling prices of goods sold by the firm, it would be more correct to disregard this factor and set the prices based on market forces prevailing at the time. However, distortion in market selling prices could occur if not all the firm's competitors are utilizing a common accounting approach, such as LIFO. This should be evaluated by the firm individually, in censultation with its marketing management. Also, care should be taken that the marketing plan of the firm is not upset by such factors as accelerated sales (at the beginning of a financial year in order to reduce the burden of maintaining a layer at the end of the previous year) or decelerated sales (towards the end of the year with a view to maintaining a layer).

\section{Rates of taxation}

A deferment of tax which results from the adoption of LIFO is subject to termination (i.e. tax becomes payable) if and when certain events occur. These events are:

(i) an erosion of all or part of a layer of inventories valued on LIFO; and/or

(ii) a fall in the price levels of inventories valued on LIFO. In both these cases, the current cost charged to the income statement will be lower and taxable income will be higher than if any other method had been used. If tax rates change, the question arises as to what will be the difference between the tax recouped and that originally deferred?

In addition, cognizance should be taken of the time value of money. For example $R 1,20$ payable in year 10 could still, on a present value basis, be cheaper than $R 1,00$ payable in year 1. Each firm should make an evaluation of the possible impact of future changes in tax rates on its projections of LIFO benefits.

It could also be contended that as more firms switch to LIFO and take advantage of other tax benefits, this will result in a cost to the fiscus which will thus be forced to raise the overall rate of tax in order to ensure that its revenue does not diminish. Under these circumstances, FIFO companies would be subsidizing LIFO companies, i.e., not only would they be paying higher rates of tax, but the rate would also be applied to a higher taxable income.

An interesting observation is that if all firms switched to LIFO, tax rates would have to rise and all firms would probably be in a similar tax situation to what they were prior to LIFO being introduced - although there would be certain redistribution of tax liability.

\section{Dividends}

Due to the lower reported earnings, such factors as dividend cover and profit available for distribution will be affected. The question arises as to whether a dividend policy which was effective prior to switching to LIFO could be maintained, ceteris paribus.

It may be argued that since the dividend cover (on a LIFO basis) will be reduced, the dividend itself should be reduced in order to maintain the cover. This is a faulty argument in that if anything, a lower dividend cover may be of a higher quality under LIFO than a higher cover under FIFO merely due to the fact that the additional cash which would otherwise have been paid as tax has now been retained in the business.

The conclusion is, therefore, that if there are two companies, one of which is on FIFO and the other on LIFO, both recording the same FIFO earnings, the LIFO company would be in a stronger position from a cash-flow point of view to pay a dividend. The FIFO company could even be paying dividends out of capital in a highly inflationary period. It is suggested therefore that a better measurement of dividend cover would be that of cash flow (as defined above) to dividend.

\section{Borrowings}

There are two aspects which need to be considered here:

(i) the need to borrow money,

(ii) the ability to borrow money.

As a result of improved cash flow due to tax deferment, it is likely that a LIFO firm's requirements for borrowing will 
be less than if FIFO was being used. However, when the LIFO company does require to borrow funds, difficulties could arise due to constraints imposed by its Articles of Association, loan or lease agreements, or exchange control regulations (in the case of companies which are more than $25 \%$ foreign owned). In each of these cases, the constraints could refer to certain balance sheet structures such as shareholders' equity, debt to equity ratio, working capital, or income statement related matters, such as return on investment, interest cover, etc.

One way of overcoming this problem would be to adopt the so-called flip-flop method of accounting (Mowszowski, 1983) thus ensuring that there would be no change in the shareholders' equity. Furthermore, any loan agreements can be structured to reflect the company's equity based on the accounting policies in operation at the time the agreement was concluded.

\section{Ratios}

Various ratios relating to gearing, profitability and activities of the company can be distorted if LIFO is adopted possibly causing confusion amongst shareholders, lenders, creditors, etc. The most important principle to bear in mind when ratios are examined is that they should not be looked at in isolation, but rather as a means of comparison against prior periods and against other companies in the same or similar industries. Sufficient information should be provided to enable analysis of ratios to be done on a common basis.

\section{An analysis of the effects of LIFO on quoted companies}

The annual financial statements of 12 companies for the years 1980, 1981 and 1982 were analysed with a view to illustrating some of the effects discussed above. Of these, seven companies had adopted LIFO by 1982 and five companies had not. (Adoption implies that all or a substantial proportion of the company's and/or its subsidiaries' inventories were valued using LIFO.)

The LIFO companies were selected on the basis that their financial statements contained sufficient information to enable the analysis to be carried out. Of the twelve companies chosen, ten comprised of pairs of companies from five different sectors on the industrial board of the JSE. An attempt was made to match these companies within their respective sectors as closely as possible so as to allow for assumptions of similar inflation rates and trading patterns within a particular industry. The other two companies, both LIFO users, were chosen without corresponding non-LIFO companies. In the case of one of them, all similar companies had adopted LIFO and in the case of the other, no suitable matching company could be found. In both cases, however, certain interesting observations were made which illustrate some of the principles contained in this paper.

The companies selected are listed in Table 1. Data were extracted from their financial statements. In the case of the nonLIFO companies, notional accounting was introduced on the basis that LIFO had been used for $80 \%$ of the 1980 and subsequent years' inventories. Inflation rates were applied using indices obtained from SA Reserve Bank Quarterly Bulletins and University of Stellenbosch Bureau for Economic Research publications entitled 'Trends - A Statistical Analysis of Economic Trends'. Prevailing interest rates (prime overdraft) were used to discount incremental LIFO cash flows without regard to possible changes in risk due to adoption of LIFO. In the case of the LIFO companies, notional accounting was introduced on the basis that LIFO had not been adopted. The
Table 1

\begin{tabular}{|c|c|c|c|}
\hline JSE Sector & LIFO Company & $\begin{array}{l}\text { Year of } \\
\text { switch }\end{array}$ & Non-LIFO Company \\
\hline Stores & $\begin{array}{l}\text { Edgars Stores Ltd } \\
\text { (EDGARS) }\end{array}$ & 1980 & $\begin{array}{l}\text { Hepworths Ltd } \\
\text { (HEPWORTHS) }\end{array}$ \\
\hline Motor & $\begin{array}{l}\text { Toyota South Africa } \\
\text { Lid (TOYOTA) }\end{array}$ & 1981 & $\begin{array}{l}\text { Dan Perkins } \\
\text { Holding Ltd } \\
\text { (DANPERK) }\end{array}$ \\
\hline $\begin{array}{l}\text { Electronics, } \\
\text { Electrical \& } \\
\text { Battery }\end{array}$ & $\begin{array}{l}\text { Scottish Cables LId } \\
\text { (SCOTTISH) }\end{array}$ & 1979 & $\begin{array}{c}\text { Aberdare Cables } \\
\text { Africa LId } \\
\text { (ABERDARE) }\end{array}$ \\
\hline $\begin{array}{l}\text { Clothing, } \\
\text { Footwear \& } \\
\text { Textiles }\end{array}$ & $\begin{array}{l}\text { Romatex Ltd } \\
\text { (ROMATEX) }\end{array}$ & 1979 & $\begin{array}{l}\text { Consolidated } \\
\text { Textile Mills } \\
\text { Investment Corp. } \\
\text { Lid (CONTEX) }\end{array}$ \\
\hline Steel \& Allied & $\begin{array}{l}\text { The Union Steel } \\
\text { Corporation of SA } \\
\text { Lid (USCO) }\end{array}$ & 1980 & $\begin{array}{c}\text { (All steel } \\
\text { companies on the } \\
\text { JSE have adopted } \\
\text { LIFO) }\end{array}$ \\
\hline $\begin{array}{l}\text { Chemicals \& } \\
\text { Oil }\end{array}$ & $\begin{array}{l}\text { AECI Ltd } \\
\text { (AECI) }\end{array}$ & Pre-1979 & $\begin{array}{l}\text { Sentrachem Lid } \\
\text { (SENTRACHEM) }\end{array}$ \\
\hline Engineering & $\begin{array}{l}\text { Stewarts \& Lloyds } \\
\text { of South Africa } \\
\text { Ltd (S \& L) }\end{array}$ & 1979 & No suitable match \\
\hline
\end{tabular}

non-LIFO figures for the LIFO companies differ from reported non-LIFO results because, for this exercise, cognizance was taken of the additional interest which would have been payable on larger borrowings due to higher tax.

The data shown in Table 2 were extracted for each of the twelve companies. The total cumulative cash-flow benefit as at 1982, including interest to date on tax deferrals, was calculated for LIFO companies. Similarly, the total cumulative cashflow benefit, including interest thereon from 1980, foregone by the non-LIFO companies was calculated. (Tax was assumed to have been payable on the last day of the financial year.)

\section{The effects on cash flow and shareholders' wealth}

In the case of the LIFO companies, the difference between actual net debt at 1982 and the calculated debt, had LIFO not been adopted, represents the total cash which the company has retained which would otherw ise have been removed from its coffers. It is made up of two components i.e., the tax deferred and the cumulative after-tax interest saving on the deferred tax to the end of its 1982 financial year. The first component is a liability which could one day become owing (although, for example, EDGARS treats the tax deferred as equity in presenting its FIFO state of affairs). The second component represents genuine net increased shareholders' wealth - it is permanent, i.e., it is reflected in the increased equity and it is money in the bank.

In the case of the non-LIFO companies, the difference between net debt at 1982 (the actual position) and what the borrowings would have been had LIFO been adopted in 1980 represents the cash which the company has paid out, but which could have been retained had LIFO been adopted. Once again, there are two components i.e. the temporary(?) cash saving of the tax deferment and the permanent cumulative after-tax interest saving on such deferred tax. Those companies which have not adopted LIFO chose to give up these benefits, and have consequently foregone an increase in their shareholders' 
Table 2

\begin{tabular}{lcc}
\hline Element of data & $\begin{array}{c}\text { LIFO-Companies } \\
\text { (R000's unless } \\
\text { stated) }\end{array}$ & $\begin{array}{c}\text { Non-LIFo } \\
\text { Companies } \\
\text { (R000's unless } \\
\text { stated) }\end{array}$ \\
\hline $\begin{array}{l}\text { (a) Profit before tax - } \\
\text { Non-LIFO }\end{array}$ & FFS* \& adjusted & FFS \& adjusted \\
(b) Profit before tax - LIFO & FFS & Notional \\
(c) Tax - Non-LIFO & FFS \& adjusted & FFS \& adjusted \\
(d) Tax - LIFO & FFS & Notional \\
(e) Profit after tax - Non-LIFO & a-c & $a-c$ \\
(f) Profit after tax - LIFO & b-d & b-d \\
(g) Cash flow (as defined on & & a-d \\
p. 73)
\end{tabular}

(h) Debt (net of cash resources) FFS \& adjusted FFS \& adjusted

(i) Equity - Non-LIFO
FFS - notional FFS \& adjusted flip-flop performed

(j) Equity - LIFO

(k) Inventory - Non-LIFO

(l) Inventory - LIFO

(m) Earnings per share (cents) - Non-LIFO

\section{FFS}

Notional

FFS

FFS FFS

Notional

FFS \& adjusted FFS \& adjusted

(n) Earnings per share (cents) - LIFO

(o) Cash flow per share (cents)

(p) Dividends per share (cents)

(q) Dividend cover (ratio) - Non-LIFO

(r) Dividend cover (ratio) - LIFO

(s) Dividend cover (ratio) - Cash Flow

(t) Net asset value - Non-LIFO per share (cents)

(u) Net asset value - LIFO per share (cents)
FFS

Notional

$\begin{array}{cc}\frac{g}{\text { No. of shares }} & \frac{g}{\text { No. of shares }} \\ \text { FFS } & \text { FFS }\end{array}$

$\frac{\mathbf{m}}{\mathbf{p}}$

$\frac{\mathbf{m}}{\mathrm{p}}$

$\frac{n}{p}$

$\frac{n}{p}$

$\frac{\mathbf{o}}{\mathrm{p}}$

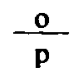

i

i

$\underline{\text { j }} \quad \underline{\text { j }}$

No. of shares No. of shares
No. of shares No. of shares

"The terms 'adjusted" and 'notional' relate in:

(i) in the cass of the I.JFO companies, the non-LIFO figures after adjustment for additional interest which would have been paid if LIFO had not been adopted.

(ii) in the case of the non-LIFO companies, the notional situation if LIFO had been adopted with respect to $80 \%$ of inventories after adjustments for interest saving on tax deferred.

•FFS - From Financial Siatements

wealth. The results are summarized in Table 3.

In the case of the LIFO companies, the saving and deferment (the total of the two together represents the difference in net debt) were achieved, whilst in the case of the non-LIFO

Table 3

\begin{tabular}{|c|c|c|c|c|c|c|}
\hline \multirow{2}{*}{$\begin{array}{l}\text { LIFO/ } \\
\text { Non-LIFO }\end{array}$} & \multirow[b]{2}{*}{ Company } & \multirow{2}{*}{$\begin{array}{c}\text { a } \\
\text { Difference } \\
\text { in Net Debt } \\
\text { R000's }\end{array}$} & \multicolumn{2}{|c|}{ Tax deferment } & \multicolumn{2}{|c|}{$\begin{array}{l}\text { Cumulative } \\
\text { after-tax } \\
\text { interest saving }\end{array}$} \\
\hline & & & R000's & $\%$ of a & R000's & $\%$ of a \\
\hline LIFO & EDGARS & 10131 & 9698 & 95,7 & 433 & 4,3 \\
\hline Non-LIFO & HEPWORTHS & 173 & 166 & 96,0 & 7 & 4,0 \\
\hline LIFO & TOYOTA & 19408 & 18660 & 96.1 & 748 & 3,9 \\
\hline Non-LIFO & DANPERK & 447 & 422 & 94.4 & 25 & 5,6 \\
\hline LIFO & SCOTTISH" & 1034 & 895 & 86,6 & 139 & 13,4 \\
\hline Non-LIFO & ABERDARE & 1313 & 1240 & 94,4 & 73 & 5,6 \\
\hline LIFO & ROMATEX & 7319 & 6653 & 90,9 & 666 & 9,1 \\
\hline Non-LIFO & CONTEX & 2303 & $2|4|$ & 93.0 & 162 & 7,0 \\
\hline LIFO & AECI & 32622 & 28478 & 87,3 & 4144 & 12,7 \\
\hline Non-LIFO & SENTRACHEM & 21382 & 20281 & 94.9 & 1101 & 5,1 \\
\hline LIFO & $S \& L$ & 18634 & 16632 & 89,3 & 2002 & 10.7 \\
\hline LIFO & USCO & 8215 & 7597 & 92,5 & 618 & 7,5 \\
\hline
\end{tabular}

(i) In addition, an arsesed loss of $R 432000$ would have been available to reduce fut ure taxable income. As the company paid $R 286000$ tax in its next financial year, this could have been reduced by $46.2 \%$ of $R 432000=R 200000$.

(ii) This is the only company analysed which, in any of the years under re ieu, paid back any lax i.e. its 1980 LIFO tax exceeded what the non-L.IFO tax would have been by R260 000 .

companies, they have been foregone. It is significant that the cumulative after-tax interest saving represents a relatively small component of the total difference in net debt. This is because the LIFO companies have only been on LIFO for a relatively short period and the assumption for the non-LIFO companies is that they only adopted it in 1980 .

It is not a difficult task for each firm to carry out this exercise on its own financial figures whether it has adopted LiFO or not in order to ascertain the effect LIFO has/would have had on its cash position and net increase in shareholders' wealth.

\section{The effect on dividends}

Table 4 contains a comparison of the dividend covers. It has been illustrated that in almost all cases, the number of times by which dividends have been covered by cash flow is substantially greater than the traditionally measured dividend cover, i.e. earnings per share (LIFO or non-LIFO) divided by dividends per share. This leads to the conclusion that dividends declared by LIFO companies have a measure of 'quality' which the non-LIFO companies lack.

Viewed from a different angle, the LIFO companies could have declared additional dividends (equivalent to the difference in net debt) without being in a worse cash position than they would have been had they not adopted LIFO and not declared such additional dividends. Hence LIFO companies can afford to increase dividends, and accordingly, reduce the cover, without the increased risk of additional debt. Thus they could distribute cash payments to their own shareholders rather than to third parties (i.e. the CIR for tax and lenders for interest). There could hardly be a more clearcut definition of creation of shareholders' wealth than this.

\section{The effect of inventory profit ratio}

An examination of the results reveals that the greatest benefits are obtained by those companies whose inventory/profit ratio is high. Although this is not the only determinant of the impact 
Table 4

\begin{tabular}{|c|c|c|c|c|c|c|}
\hline \multirow[b]{2}{*}{ Company } & \multicolumn{2}{|c|}{$\begin{array}{l}\text { Dividend cover } \\
\text { - Non-LIFO - }\end{array}$} & \multicolumn{2}{|c|}{$\begin{array}{c}\text { Dividend cover } \\
\text { - LIFO - }\end{array}$} & \multicolumn{2}{|c|}{$\begin{array}{l}\text { Dividend cover } \\
\text { - Cash flow - }\end{array}$} \\
\hline & Average $^{\mathbf{j}}$ & Rangeii & Average & Range $^{i j}$ & Average' & Range ${ }^{i i}$ \\
\hline EDGARS & 2,5 & $2,5-2,6$ & 2,1 & $2,0-2,2$ & 2,9 & $2,8-2,9$ \\
\hline HEPWORTHS & 9,6 & $9,1-10,1$ & 6,2 & $4,1-8,3$ & 10,8 & $10,6-10,9$ \\
\hline TOYOTA & 7,2 & $5,3-9,3$ & 5,0 & $3,1-6,9$ & 9,1 & $7,5-10,6$ \\
\hline DANPERK & 2,4 & $1,7-2,9$ & 2,1 & $1,3-2,6$ & 2,7 & $1,9-3,3$ \\
\hline SCOTTISH & 1.5 & $1,3-1,6$ & 1.5 & $1.5-1.5$ & 1,5 & $1.3-1.7$ \\
\hline ABERDARE & 2,3 & $1,8-3,0$ & 2,2 & $1.7-2,9$ & 2,4 & $2,0-3,1$ \\
\hline ROMATEX & 2,1 & $1,7-2,4$ & 2,0 & $1,6-2,4$ & 2,2 & $1.8-2.5$ \\
\hline CONTEX & 10,2 & $9,5-10,8$ & 8,9 & $8,2-10,0$ & 11,3 & $11,0-11,8$ \\
\hline AECI & 1,9 & $1,7-2,2$ & 1,8 & $1,6-2,0$ & 2,0 & $1,8-2,3$ \\
\hline SENTRACHEM & 2,3 & $2,2-2,3$ & 2.0 & $1,9-2,2$ & 2,5 & $2,4-2,5$ \\
\hline$S \& L$ & 2,8 & $2,8-2,9$ & 2,1 & $1,9-2,3$ & 3,5 & $3,3-3,6$ \\
\hline USCO & 4,1 & $3,7-4.8$ & 3,0 & $2,8-3,2$ & 5,1 & $4,3-6,7$ \\
\hline
\end{tabular}

(i) Arithmetic mean of 1980, 1981 and 1982 cosers

(ii) Range of covers betwcen 1980, 1981 and 1982

of LIFO on reported earnings (other factors such as rate of inventory increase, rate of inflation, etc. all interact), the greater the inventory/profit ratio, the greater the divergence between reported LIFO and non-LIFO earnings.

\section{Communication}

A brief analysis was made of the references to LIFO in the annual reports of the LIFO companies (from chairman's statement, notes, directors' report, etc.). Table 5 contains a synopsis of such references.

Communication was generally found to be lacking. Companies seem to have ignored the LIFO dilemma with which they are faced. In other words, they have adopted LIFO and obtained the cash-flow benefits, but they have generally not made sufficient attempt to communicate the consequences of the change to their publics. Of the ninety-two LIFO users quoted in the JSE industrial sectors, six provided so little information in their latest annual reports that the effect of LIFO on earnings, tax or shareholders' equity could not be determined. Notable exceptions are S \& $\mathrm{L}$ and EDGARS, who go out of their way to achieve the best of both worlds, i.e. to obtain the cash-flow benefits, and also to ensure that these are positively impacted in the prices of their respective shares.

Finally the following observations were made after a study of media announcements and editorials consequent upon publication of the results of companies using LIFO:

(i) In no instances was the concept of cash flow utilized.

(ii) Comparisons of performances of LIFO and non-LIFO companies are often confused. An example of this is contained in Appendix 1 which is an extract from a supplement to the Financial Mail of 18 November, 1983. No mention was made, either in the comparison or in the accompanying analysis and interpretation, of the fact that Anglo Alpha and PP Cement are LIFO users and Blue Circle is not.

(iii) The JSE Data Bank which is published in the newspapers reflects earnings yields and/or price-earnings ratios only on the basis adopted by the company. A cursory glance at a newspaper could therefore be totally misleading or at the very best, incomplete.

\section{Conclusions}

The effect of LIFO on JSE quoted industrial companies is only
Table 5 References to LIFO in financial statements of companies listed on the JSE

\begin{tabular}{|c|c|}
\hline Company & Reference \\
\hline usco & $\begin{array}{l}\text { FIFO value of inventory is reflected. Therefore, LIFO } \\
\text { reserve ascertainable. EPS in five year revies on LIFO } \\
\text { and FIFO. Other ratios in five year review in LIFO on- } \\
\text { ly. No indication of LIFO effect on earnings for year } \\
\text { (except EPS and the fact that it is ascertainable by } \\
\text { comparing LIFO reserve with that of previous year). }\end{array}$ \\
\hline $\operatorname{sco}$ & $\begin{array}{l}\text { Very sketchy information. Chairman's statement con- } \\
\text { tains reference to effect of LIFO on year's trading. No } \\
\text { cumulative effect shown. No mention made in five year } \\
\text { performance charts, directors' report or interim results } \\
\text { statements. }\end{array}$ \\
\hline
\end{tabular}

TOYOTA Discloses effect of LIFO on earnings. Reflects LIFO and FIFO results and asset values since adoption of LIFO in ten year review including EPS and dividend cover. Cumulative LIFO reserve not directly reflected but ascertainable by adding together each individual year's LIFO difference.

AECl No effect of LIFO on earnings is reflected. The only figure reflected is the cumulative LIFO reserve and by comparing with that of previous year, effect can be ascertained. It is interesting to note, however, that in the five year review, return on assets is calculated on the basis of inventories at FIFO.

EDGARS Excellent disclosure. Full five year review on both LIFO and FIFO. Full income statement reflected on LIFO and FIFO bases. Chairman alludes to the improvement in quality of earnings and increase in cash flow. The five year review is FIFO reported, and it transfers the full amount of the FIFO reserve to Nondistributable Reserve (equity) without providing for deferred tax thereon.

ROMATEX Five year review reflected in LIFO only, e.g., cash flows, EPS, return on average shareholders' fund etc., although net asset value is reflected in LIFO and FIFO. LIFO adjustment for year is shown, therefore the LIFO reserve can be calculated. However, under assets, inventory is reflected at LIFO only. Certain target ratios expressed in LIFO, others in FIFO.

S \& L Excellent awareness of need to communicate with shareholders with regard to effect of LIFO. Initially sent out brochure on adoption of LIFO. The LIFO reserve is shown in five year review, as are LIFO and FIFO comparisons of earnings, EPS and dividend cover. It is interesting to note that net asset value is expressed at FIFO only. 
now beginning to take on meaningful proportions. With the passage of time and the high inflation rates experienced in South Africa, the cumulative effect of rising LIFO reserves and tax deferments will have a substantial influence on corporate cash flows and shareholders' wealth. Communication, however, tends to lag and companies will need to improve this aspect if they are to maximize the benefits attainable through an adoption of LIFO. It is also interesting that a company such as SENTRACHEM is enlightened enough to disclose information such as NOPAT (net operating profit after tax), COPAT (cash operating profit after tax) and FCF (free cash flow) along the lines of the Economic Earnings Model, yet it has not adopted LIFO in order to gain real cash-flow benefit.

It is intriguing that not many more companies have adopted LIFO. In the case of companies quoted on the JSE, by June 1983 , only $31 \%$ of industrial companies had adopted LIFO. In the case of private companies, the proportion is minimal. Mann (1982) conducted a survey of 350 private companies and of the ninety-two respondents, only five had adopted LIFO, seven were fully aware of LIFO but had rejected it, two had heard of LIFO but had not considered it in depth, five had heard of LIFO but were unaware of what it is or can do, and seventy-three had never heard of LIFO.

It is clear that there is inadequate communication directed at companies (particularly private companies) with the aim of educating and demonstrating the benefits available from LIFO adoption. What other rationale can exist for the fact that, for five of the JSE LIFO companies analysed in this paper, there are companies operating in the same industry, under the same economic environment and in certain instances, even handling identical products, yet LIFO had not been adopted? Perhaps shareholders of non-LIFO companies should require management to advance their reasons for non-adoption.

It is also evident that there is a wide spectrum of parties which require further education with respect to LIFO benefits. These include auditors, analysts, investment advisers, stock- brokers, bankers and investors. If all these parties were made to be acutely aware of the potential benefits, it is believed that many more companies would adopt LIFO.

Nevertheless, the already existing body of LIFO adopters is known to be a worry to the revenue authorities. Mr Mickey van der Walt, the CIR, speaking at the 1983 Financial Mail Investment Conference in Johannesburg, criticized the exploitation of tax concessions. What he was referring to when he used the term 'exploitation' is not quite clear, but it seems that he was alluding to companies who adopted LIFO purely as a mechanism to obtain tax relief rather than those who genuinely believed that LIFO is the most suitable method of valuing inventories for the actual business conducted. It also lends support to the hypothesis that if all firms adopted LIFO, tax rates would have to be increased and that until such time as this occurs, non-LIFO companies are, in effect, subsidizing LIFO companies.

Notwithstanding that there are conflicting conclusions abroad regarding the effect of LIFO adoption on share values (although the more recent studies tend to favour the cash-flow hypothesis rather than the functional fixation hypothesis), it is contended that further research should be conducted in South Africa to ascertain whether the trend referred to by Knight and Affleck-Graves (1983) is continuing i.e. is the market becoming more aware of the LIFO benefits and if so, is such awareness being impacted positively into share prices of industrial companies on the JSE?

Pending such research, companies which have adopted, or are contemplating the adoption of LIFO, should have little fear that negative impact on share price will result, provided that the communication and education process continues, i.e., provided the market is fully informed of the company's cash flows, and media such as newspapers, JSE handbooks, financial publications, stockbrokers' bulletins and the like, are designed to provide full information of LIFO and non-LIFO situations and cash flows. A most important final proviso is

\begin{tabular}{|c|c|c|c|c|}
\hline \multirow{3}{*}{ Debt } & \multicolumn{4}{|c|}{ How they compare* } \\
\hline & Anglo-Alpha & Blue Circle & PP Cement & PP Cement \\
\hline & $\begin{array}{c}\text { Year ended } \\
31.12 .82\end{array}$ & $\begin{array}{c}\text { Year ended } \\
30.11 .82\end{array}$ & $\begin{array}{c}\text { Year ended } \\
30.9 .82\end{array}$ & $\begin{array}{c}\text { Year ended } \\
30.9 .83\end{array}$ \\
\hline Short-term (Rm) & 9,1 & 28,4 & 3,3 & - \\
\hline Long-term (Rm) & 95,9 & 61.4 & 21,9 & - \\
\hline Debt equity ratio & 0,30 & 0.56 & 0,11 & - \\
\hline Shareholders interest & 0,60 & 0.47 & 0,61 & - \\
\hline Interest \& leasing cover & 7,5 & 2,5 & 28,6 & - \\
\hline Debt cover & 0,96 & 0.43 & 3,2 & - \\
\hline Return on capital $(\%)$ & 12,1 & 10.7 & 21,3 & - \\
\hline Turnover (Rm) & 252,9 & 305 & 270,7 & 290,7 \\
\hline Pre-interest profit ( $\mathbf{R m})$ & 70,2 & 34,2 & 83,1 & 88,7 \\
\hline Pre-interest margin $(\%)$ & 26,1 & 11,2 & 29,8 & 31,0 \\
\hline Earnings (cents/share) & 90,4 & 86,2 & 247,6 & 264,9 \\
\hline Dividends (cents/share) & 42 & 38,5 & 64 & 70,0 \\
\hline Dividend cover & 2,1 & 2,2 & 2,9 & 3,8 \\
\hline Net asset value (cents/share) & 1139 & 728 & 288 & - \\
\hline
\end{tabular}

- Pretoria Portland Cement. A corporatc report.

Supplement to Financial Mail November 18 1983, p.31. 
the one that, in the first instance, it is encumbent on the company itself to provide as much information as possible to ensure that analysis and comparison with other companies are facilitated after adjusting for the effect of LIFO, if the company is to gain maximum benefit from the adoption of LIFO.

\section{References}

Alex Aiken \& Carter. July 1983. LIFO Bulletin.

Brealey, R. \& Myers, S. 1981. Principles of Corporate Finance. New York: McGraw-Hill.

Counihan, P.F. \& Watts, R.L. 1978. The implication of LIFO for share prices. The South African Chartered Accountant, vol. 14, no. 3, 90-94.

Fama, E.F. 1970. Efficient capital markets - a review of theory and empirical work. Journal of Finance, vol. 25, 384-417.

Gilbertson, B.P. \& Roux F.J.P. 1977. The Johannesburg Stock Exchange as an efficient market. The Investment Analysts Journal, vol. 9, $21-27$.

Gilbertson, B.P. \& Vermaak N.M. 1982. The performance of South African mutual funds: $1974-1981$. The Invesiment Analysts Journal, vol. 20, 35-45.

Hoyle R.F. 1981. Tax savings from LIFO when stock levels reduce. The South African Chartered Accountant. Vol. 17, no. 12, $555-556$.

Knight, R.F. 1981. The efficient market hypothesis and a change to LIFO: An empirical study on the Johannesburg stock exchange. Unpublished M. Comm. Thesis, University of Cape Town.

Knight, R.F. \& Affleck-Graves J.F. 1983. The efficient market hypothesis and a change to LIFO. An empirical study on the JSE. The Investment Analysts Journal. vol. 21, 21-33.

Mann, K.A. 1982. A framework for the formation of a business venture in the fieids of training and/or accounting services. Unpublished MBL dessertation, University of South Africa.

Mowszowski, N.P. 1983. Financial implications of the LIFO method of valuing inventories. Unpublished MBA research report, University of the Witwatersrand. 